\title{
JUURNAL.RU
}

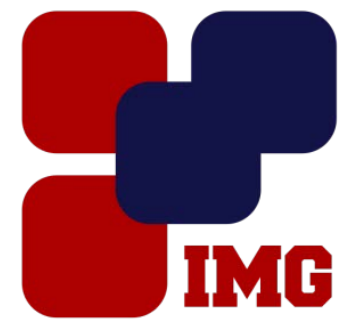
IYANOY Management GROUP

Корбут Т.Н. Горно-Алтайский государственный университет Горно-Алтайск, Россия

doi: 10.18411/lj-31-01-2017-4-07

idsp 000001:lj-31-01-2017-4-07

\section{Динамико-стохастическое моделирование поверхностного стока}

Задача, решения прогнозирования повышения уровня вод в реках Республики Алтай является одной из приоритетных, в связи с меняющимися климатическими условиями. Формирование поверхностного стока, который большое влияние оказывает на уровень рек республики из-за физикогеографических (рельеф) особенностей, зависит от большого числа процессов и параметров. Перспективой исследования взаимосвязи всех параметров связаны с применением динамико-стохастических моделей со случайными «входами», учитывающими вероятностную природу метеорологических процессов и физические (детерминистические) механизмы формирования поверхностного стока[1, 2].

Применение динамико-стохастических моделей является динамично развивающимся направлением. Для повышения надежности физикоматематических моделей формирования стока связывают с возможностями насыщения их более подробной детерминистической информацией: уточнением описания отдельных гидрологических процессов с учетом ранее неизвестных или недооцениваемых физических механизмов, включением новых экспериментально установленных связей между гидрологическими переменными, между параметрами модели и характеристиками водосбора, а учет различных источников неопределенности, присутствующих в детерминистической модели, достигается включением в нее соответствующей стохастической информации. Поэтому, для вероятностных оценок характеристик возможных гидрографов стока одним из наиболее перспективных подходов является использование динамико-стохастических моделей формирования речного стока, где на входе физико-математических моделей формирования стока используются стохастические модели метеорологических воздействий на водосбор [3]. Для разработки динамико-стохастической моделей формирования стока возможно использование таких 
метеорологическихпараметров как среднесуточные, значения температуры и относительной влажности воздуха, суточные суммы осадков, толщина снега [1].

В связи со сложным рельефом местности Республики Алтай актуальной задачей является рассмотреть применение данных дистанционного зондирования Земли [4] в построении динамико-стохастической модели формирования стока.

\section{Литература}

1. Гельфан А.Н. Динамико-стохастическое моделирование формирования снежного покрова на Европейской территории России/ А.Н. Гельфан, В.М. Морейдо//Лед и снег.2014. №2

2. Гельфан А.Н. Динамико-стохастическое моделирование процессов гидрологического цикла речного бассейна / Гельфан А.Н.//Наука, 2007.- 280 с.

3. Кучмент Л.С. Совершенствование научно-методической базы расчетов и прогнозов речного стока на основе физико-математических моделей его формирования/ Л.С. Кучмент [и др.]//VII Всероссийский съезд, 2013

4. Кучмент Л.С. Использование спутниковой информации о характеристиках снежного покрова в физико-математической модели формирования весеннего половодья/Л.С.Кучмент [идр.]// Современные проблемы дистанционного зондирования земли из космоса, 2010. №2.- 167 с. 